\title{
NILAI KARAKTER BERBASIS KEARIFAN LOKAL TRADISI TEPUNG TAWAR PADA ETNIS MELAYU SAMBAS
}

\author{
Hemafitria \\ Program Studi PPKN Fakultas Ilmu Pendidikan dan Pengetahuan Sosial IKIP PGRI Pontianak \\ Jalan Ampera Nomor 88 Pontianak, Telepon (0561) 748219 Fax. (0561) 6589855 - 78116 \\ email: rizkyema10@gmail.com
}

\begin{abstract}
Abstrak
Salah satu nilai yang dapat dijadikan landasan pengembangan karakter anak adalah nilai-nilai kebaikan suatu daerah yang mengakar kuat sebagai sistem budaya, yang kemudian disebut sebagai kearifan lokal. Kearifan lokal tepung tawar merupakan tawaran yang menarik untuk pengembangan pendidikan karakter, karena pada dasarnya pengembangan karakter harus diikuti dengan integrasi identitas nasional pada anak, identitas nasional atau nasionalisme pasti akan terkait erat dengan jaringan budaya nasional. Penelitian ini adalah penelitian deskriptif dengan pendekatan kualitatif. Teknik analisis data yang digunakan dalam penelitian ini terdiri dari tiga kegiatan yaitu reduksi data, penyajian data, penarikan kesimpulan/verifikasi. Berdasarkan temuan bahwa Tradisi Tepung Segar memiliki Nilai Karakter Berdasarkan Kearifan Lokal Komunitas Melayu Sambas. Tradisi kelahiran tepung tawar : 1) nilai-nilai agama, syukur dapat dikontekstualisasikan menjadi karakter agama, 2) nilai kesatuan dengan alam dapat dikontekstualisasikan menjadi karakter tanggung jawab dan disiplin, dan 3) nilai-nilai sosial, cinta dan kasih sayang, juga karena keselamatan dan kehidupan yang baik dapat dikontekstualisasikan menjadi karakter kasih sayang, perhatian, dan kerja sama. Kearifan lokal menjadi tawaran yang menarik bagi pengembangan pendidikan karakter, karena pada dasarnya pengembangan karakter harus diikuti dengan integrasi identitas nasional dalam warganegara.
\end{abstract}

Kata Kunci : Karakter, Kearifan Lokal, Tradisi Tepung Tawar, Melayu Sambas

\begin{abstract}
One of the values that can be used as a foothold for the development of children's character is the values of the goodness of an area that is deeply rooted as a cultural system, which is then referred to as local wisdom. The local wisdom of the traditional Tepung tawar is an attractive offer for the development of character education, because basically character development must be followed by the integration of national identity in children, national identity or nationalism will certainly be closely linked to the national cultural network which is the basis of national culture. This research is a descriptive study with a qualitative approach. Data analysis techniques used in this study consisted of three activities that occurred simultaneously, namely data reduction, data presentation, drawing conclusions / verification. Based on the findings that the Tradition Tepung Tawar has Character Values Based on Local Wisdom of the Sambas Malay Community. The tradition Tepung tawar birth 1) religious values, gratitude can be contextualized into religious characters, 2) the value of oneness with nature can be contextualized into a character of responsibility and discipline, and 3) social values, love and affection, as well as safety and good life can be contextualized be the character of Affection, caring and cooperation. Local wisdom becomes an attractive offer for the development of character education, because basically the development of character must be followed by the integration of national identity in the citizens.
\end{abstract}

Keyword: Character, Local Wisdom, Tradisi Tepung Tawar, Melayu Sambas

\section{PENDAHULUAN}

Dewasa ini, makin disadari pentingnya pendidikan karakter dalam upaya pengembangan sumber daya manusia suatu bangsa. Berbagai kajian dan fakta menunjukkan bahwa bangsa yang maju adalah bangsa yang memiliki karakter kuat. Nilai-nilai karakter tersebut adalah nilai-nilai yang digali dari khasanah budaya yang selaras dengan karakteristik masyarakat setempat (kearifan lokal) dan bukan "mencontoh" nilainilai bangsa lain yang belum tentu sesuai dengan karakteristik dan kepribadian bangsa tersebut. 
Naritoom (Wagiran, 2010) merumuskan local wisdom dengan definisi, "Local wisdomis the knowledge that discovered or acquired by lokal people through the accumulation of experiences in trials and integrated with the understanding of surrounding nature and culture. Local wisdom is dynamic by function of created local wisdom and connected to the global situation." Definisi kearifan lokal tersebut, palingtidak menyiratkan beberapa konsep, yaitu: (1) kearifan lokal adalah sebuah pengalaman panjang, yang diendapkan sebagai petunjuk perilaku seseorang; (2) kearifan lokal tidak lepas dari lingkungan pemiliknya; dan (3) kearifan lokal itu bersifat dinamis, lentur, terbuka, dan senantiasa menyesuaikan dengan zamannya. Konsep demikian juga sekaligus memberikan gambaran bahwa kearifan lokal selalu terkait dengan kehidupan manusia dan lingkungannya. Kearifan lokal muncul sebagai penjaga atau filter iklim global yang melanda kehidupan manusia.

Esensi kemajuan yang dicapai berbagai bangsa tersebut menunjukkan bahwa pengembangan karakter suatu bangsa tidak dapat dilepaskan dari aspek budaya yang selaras dengan karakteristik masyarakat bangsa itu sendiri. Budaya yang digalidari kearifan lokal bukanlah penghambat kemajuan dalam eraglobal, namun justrumenjadi filter budaya dan kekuatan transformasional yang luar biasa dalam meraih kejayaan bangsa. Oleh karena itu, menggali nilainilai kearifan lokal merupakan upayastrategis dalam membangun pendidikan karakter bangsadi eraglobal. Salah satu nilai kearifanlokal yang berkembang dan potensial dikembangkan, khususnya dalam ranah budaya yang ada di salah satu daerah Kalimantan Barat yaitu pada masyarakat melayu Sambas dalam tradisi Tempung tawar sebagai dasar dalam upaya penguatan karakter sumberdaya manusia.

Sambas sebagai salah satu daerah yang pernah memiliki kerajaan Melayu di Kalimantan Barat ternyata menyimpan beragam kearifan lokal yang tidak lepas dari sentuhan Islam. Hal ini karena di satu sisi Islam yang datang di bumi Nusantara termasuk Sambas, Kalimantan Barat telah melakukan akulturasi dengan budaya setempat yang memang sudah dahulu ada dan ternyata juga memiliki budaya yang bermacam-macam. Etnis Melayu Sambas dalam konteks kajian ini dimaksudkan adalah masyarakat Secara religi, masyarakat Melayu Sambas adalah Melayu yang beragama Islam dan memang Melayu identik dengan orang Islam atau Muslim.

Kajian ini akan dapat dikembangkan sesuai perspektif yang ditekuni sehingga menjadi khazanah keilmuan atau pendidikan. Bagi budayawan sebagai mediator sekaligus inspirator dalam memperkenalkan budaya lokal pada generasi selanjutnya. Bagi pendidik sebagai bahan untuk disikapi dalam memberikan pencerahan dan kedamaian pada masyarakat agar menjadi masyarakat terdidik sekaligus berbudaya tanpa kehilangan nilai-nilai fundamental atau agama. Bagi peserta 
didik umumnya sebagai perkenalan khazanah budaya nusantara yang perlu dihargai dan dihormati dalam rangka kesatuan dan persatuan bangsa. Sedangkan bagi masyarakat Sambas khususnya Melayu menjadi identitas diri dan kebanggaan dalam menjalin tatanan masyarakat yang lebih harmonis bersama etnis lainnya tanpa adanya konflik. Kajian ini akan difokuskan pada "Nilai Karakter Berbasis Kearifan Lokal tradisi Tepung Tawar Etnis Melayu Sambas”. Karena kearifan lokal dalam bentuk tradisi ini diperkirakan mungkin dimiliki oleh setiap daerah dan etnis di Nusantara. Namun, hanya mungkin berbeda dalam bentuk prosesi dan perangkat serta makna yang terkandung padanya.

\section{METODE}

Penelitian ini merupakan sebuah penelitian deskriptif dengan pendekatan kualitatif. Bogdan dan Taylor dalam Moloeng (2007: 4) mendefinisikan penelitian kualitatif sebagai prosedur penelitian yang menghasilkan data deskriptif berupa kata-kata tertulis atau lisan dari orang-orang dan perilaku yang diamati dari fenomena yang terjadi. Lebih lanjut Moleong (2007:11) mengemukakan bahwa penelitian deskriptif menekankan pada data berupa kata-kata, gambar, dan bukan angka-angka yang disebabkan oleh adanya penerapan metode kualitatif. Pengambilan sampel atau sumber data pada penelitian ini dilakukan secara puposive dan untuk ukuran sampel tersebut ditentukan secara snowball, taknik pengumpulan dengan triangulasi (gabungan), analisa data bersifat kualitatif dan hasil penelitian menekankan makna generalisasi.

Sumber data dalam penelitian ini adalah informan sebagai yang terdiri dari tokoh Adat, tokoh agama dan tokoh masyarakat Sambas. Teknik pengumpulan data dengan perekaman dan wawancara. Satori dan Komariah (2011:131) menyatakan bahwa wawancara adalah proses mendapatkan informasi untuk kepentingan penelitian dengan cara berdialog antara peneliti dengan informan. Teknik analisis data yang digunakan dalam penelitian adalah teknik analisis model interaktif. Menurut Miles dan Huberman (2014: 16-18) Analisis model interaktif meliputi tiga komponen penting yang selalu bergerak, yaitu reduksi data, penyajian data, dan penarikan simpulan melalui pelukisan dan verifikasi kemudian hasil verifikasi disesukan dengan perumusan masalah.

\section{HASIL DAN PEMBAHASAN}

\section{Tradisi Tepung Tawar Masyarakat Sambas}

Berdasarkan temuan bahwa tradisi Tepung Tawar merupakan tradisi yang pertama kali diadakan dalam kehidupan oleh masyarakat Melayu Sambas. Yakni dimulai pada kelahiran bayi. Tradisi ini dilakukan masyarakat Melayu Sambas agar adanya keselamatan yang diberikan Allah 
kepada hambaNya. Walaupun tradisi ini yang pertama dilakukan dalam kehidupan, namun masyarakat Melayu Sambas juga melakukan tradisi Tepung Tawar pada momen-momen tertentu seperti setelah khitanan, saat mendirikan rumah baru, hal ini dilakukan tepatnya ketika memasang kerangka atas bagian rumah, sembuh setelah sakit Tepung Tawar dilakukan yang disebut Betambe, ketika sebelum prosesi pernikahan bagi calon pengantin Tepung Tawar juga dilakukan.

Berdasarkan hasil wawancara yang dilakukan kepada sesepuh adat dan tokoh agama masyarakat Melayu Sambas Long Amat (70 Tahun) menyatakan bahwa Tradisi Tepung Tawar, merupakan tradisi memercikan Air Kasai Langger, yakni berupa air campuran dari beberapa bahan seperti tepung beras, serbuk langger, serbuk kayu manis dan air tolak bala yang semua bahan tersebut dipapaskan (percikan) dengan menggunakan media tumbuhan daun mali, juang dan antibar dengan tujuan keselamatan.

Tradisi Tepung Tawar merupakan sebuah simbol pengupayaan keselamatan atas apa yang telah dimiliki atau diusahakan. Keselamatan terhadap yang dimiliki seperti kelahiran anak agar tidak mendapat penyakit, atau keselamatan tidak diganggu oleh makhluk halus yang sering dialami anak ketika masih bayi. Ataupun keselamatan dalam arti umur yang panjang penuh berkah sampai akhir hayat. Atau keselamatan dan keberkahan saat mendirikan rumah. Bahwa rumah yang akan didirikan terhidar dari musibah atau bencana atau penghuni rumah itu sendiri yang akan menempati rumah tidak akan mendapat gangguan dari mahluk halus. Atau keselamatan dan keberkahan setelah dilakukan khitanan bagi anak laki-laki. Bahwa anak laki-laki tersebut nantinya ketika dewasa dan menjalani kehidupan akan selamat dunia akhirat dengan tetap menjaga kewajiban terhadap apa yang diperintahkan agama.

Sementara itu, Long Kedok (60 tahun) merupakan tokoh masyarakat mengatakan bahwa tradisi Tepung Tawar memang dilakukan dalam masyarakat Melayu saat kelahiran bayi, namun juga dilakukan saat seseorang akan menginjak dewasa tepatnya bagi laki-laki setelah melakukan khitanan. Kemudian tradisi Tepung Tawar kadang dilakukan oleh orang Melayu setelah sembuh dari sakit yang lama dideritanya, atau juga dilakukan oleh calon pengantin ketika hendak melangsungkan pesta perkawinan. Tetapi menjadi kelaziman dalam masyarakat Melayu Sambas bahwa tradisi Tepung Tawar selalu diidentikan adanya kelahiran bayi yang kadang sekaligus dilakukan Tempung tawar pada bayi.

Tradisi Tepung Tawar dilakukan karena kelahiran bayi dan disertai Tempung tawar bahwa terdapat media tertentu yang digunakan saat prosesi. Adalah kelapa muda beserta airnya, air tolak bala, air kasai langger, daun sirih, beras kuning, daun juang, mali dan antibar. Semua media tersebut mengisyaratkan adanya nilai-nilai. Adalah buah karena memiliki beberapa nilai 
keutamaan, kemurnian dan kejernihan. Daun sirih memiliki nilai kasih sayang yang sangat kental dan terus dipertahankan dalam aktivitas tertentu. Daun juang seperti terdapat di pemakaman muslim melambangkan adanya nilai perjuangan melawan syaitan, daun mali adalah nama tumbuhan yang diambil dari bahasa arab mal yang berarti harta merupakan simbol kekayaan.

Menurut Uning Muin (62 Tahun,) bahwa Air Tolak Bala adalah lambang kesempurnaan sekaligus keselamatan, air Kasai Langger memiliki nilai kebersihan lahiriyah dan bathiniyah diyakini mampu menghapus sifat-sifat jelek dan memunculkan sifat benar dan jujur. Sedangkan media Beras Kuning adalah beras biasa yang dilumuri kunyit sehingga berwarna kuning, baik menurut Long Amat, Long Kedok memiliki nilai kebaikan. Pada tradisi Tepung Tawar atas kelahiran anak juga dihamburkan barras kuning dengan harapan kebaikan dan keselamatan atasnya.

Berdasarkan temuan penelitian di atas, maka berdasarkan perspektif emik masyarakat Melayu Sambas bahwa Tepung Tawar merupakan tradisi yang dilakukan berkaitan dengan kepemilikan dan usaha yang dilakukan dalam rangka mendapatkan keberkahan berupa keselamatan dan manfaat dalam kehidupan dunia maupun akhirat. Dalam penelitian ini, tradisi Tepung Tawar difokuskan pada pengamatan pada tradisi Tepung Tawar atas kelahiran anak.

Tradisi Tepung Tawar dalam masyarakat Melayu Sambas kaya akan nilai atau makna. Nilai atau makna baik diartikan sebagai sebuah atau serangkaian konsep yang memuat keutamaan atau kebermanfaatan yang dapat dijadikan pembelajaran bagi mereka yang mempunyai keyakinan yang disertai nalar bahkan mampu membuat hubungan dalam menata kehidupan yang dapat dibuktikan karena didalamnya memiliki kebijaksanaan atau kearifan. Pengalian dan pengkajian terhadap tradisi Tempung tawar dalam masyarakat Sambas sehingga menghasilkan makna atau nilai.

\section{Nilai-nilai karakter dalam Kearifan Lokal Tradisi Tepung Tawar}

Adapun nilai-nilai yang dapat digali pada tradisi Tepung Tawar berdasarkan temuan peneliti dapat dipaparkan sebagaimana berikut.

Pertama, nilai kesatuan dengan alam. Bicara tentang nilai karakter berarti ada dua konsep yang harus diketahui, yaitu, nilai dan pendidikan karakter. Menurut Max Scheler (Masdukin 2013:74) menyatakan nilai merupakan sesuatu kenyataan yang pada umumnya tersembunyi dibalik kenyataan-kenyataan lain. Menurut Long Amat Alam dalam pandangan masyarakat Melayu Sambas merupakan sesuatu yang harus dijaga dan diperlakukan secara baik demi kemaslahatan manusia. Alam banyak menyiapkan dan memberikan manfaat kepada manusia. Oleh karena itu, tradisi Tepung Tawar menurut Along Musni (68 tahun) dapat mengingatkan manusia 
akan nilai bahwa manusia dalam kehidupannya selalu berhubungan alam apalagi semua media yang digunakan ketika pelaksanaan Tepung Tawar berasal dari unsur alam.

Kedua, nilai syukur. Masyarakat Melayu Sambas yang agamis akan mengetahui betul dalam mensikapi setiap karunia yang diberikan Allah SWT. Oleh karena itu, tradisi Tepung Tawar sebenarnya diarahkan agar ada rasa syukur atas anugerah terindah dan istimewa yang Allah berikan berupa kelahiran anak. Dengan demikian nilai syukur yang diiringi harapan keselamatan dunia akhirat sebenarnya juga menegaskan akan adanya nilai keberagamaan seorang muslim, karenanya kedua nilai ini sebenarnya menunjukkan nilai agama.

Ketiga, nilai agama, selain rasa syukur dan pengharapan keselamatan yang dilekatkan dalam tradisi Tepung Tawar, jelasnya tradisi ini juga dilakukan dengan serangkaian shalawat yang dalam penegetahuan bahasa lokal disebut Nyalai dan Syarakalan serta disudahi dengan doa Tolak bala oleh pak Lebai. Menurut Long Amat dan dikuatkan oleh pakar budaya Kalimantan Barat Ning Fa'i (65 tahun) bahwa Nyalai dan Syarakalan baik dalam tradisi Saprahan dan tradisi Tepung Tawar atas kelahiran anak apalagi diikuti dengan pelaksanaan aqiqah sebenarnya menujukan tradisi tersebut sangat bermuatan nilai agama.

Keempat, nilai sosial, Secara sosial-budaya, Tepung Tawar dilakukan sebagai sebuah tradisi memang diwariskan dari generasi ke generasi sehingga menjadi sebuah nilai yang harus dilaksanakan sebagai wujud kebahagiaan yang dirasakan bersama-sama sebagai warga masyarakat beradat atas hadirnya manusia baru dalam keluarga tertentu. Sehingga tidak heran wujud kebahagiaan bersama itu, selain dikabarkan kepada khalayak ramai juga dirangkai dengan jamuan makan bersama yang disebut Saprahan.

Kelima, cinta dan kasih sayang. Karena bayi diajarkan dan dipersiapkan dengan ilmu dan keimanan untuk melawan syaitan ini membuktikan adanya kasih sayang orang tua. Kasih sayang itu tidak hanya sebatas dunia semata namun melampau cinta untuk kebaikan akhirat. Maka jelas sudah bahwa tradisi Tempung tawar sejatinya juga mengarahkan adanya nilai cinta dan kasih sayang.

Keenam, keselamatan dan kebaikan hidup. Cinta dan kasih sayang orang tua yang tidak hanya berorientasi duniawi namun juga ukhrawi sebetulnya pengharapan akhirnya adalah keselamatan dan kebaikan. Keselamatan dan kebaikan ini juga berorientasi dunia dan ukhrawi. Secara dunia keselamatan tidak mendapat kecelakaan dunia secara ukhrawi juga tidak ingin anaknya kelak mendapat celaka akhirat. Jadi di balik tradisi Tempung tawar kedua makna keselamatan dan kebaikan tersebut nampaknya menjadi esensi kunci dalam menjadi kehidupan. 
Dengan demikian berdasarkan perspektif emik masyarakat Melayu Sambas terhadap tradisi Tepung Tawar maka nilai-nilai kearifan lokal sebagaimana tersebut di atas sebenarnya bermuara core values, nilai inti yakni keselamatan. Nilai keselamatan yang didasari secara adat dan agama. Secara adat bahwa nilai keselamatan dijelaskan melalui media-media yang digunakan. Sedangkan nilai secara agama bahwa tradisi Tepung Tawar dinyatakan dan diperlihatkan melalui kegiatan dengan memasukan Nyalai dan Syarakalan yakni melantunkan pujian terhadap Nabi Muhammad sebagaimana terdapat dalam kitab barzanji serta pembacaan rawi mulai dari bacaan lafadz bada'tubiis dan lafadz walam taskufi dan ditutup dengan doa Tolak Bala oleh seorang Lebai.

Berdasarkan analisa nilai-nilai, simbol dan properti serta proses maupun yang terlibat di dalam tradisi Tempung tawar dalam konteks masyarakat Melayu Sambas, maka dapat ditarik kesimpulan sebagai berikut. Pertama, perspektif unsur-unsur kebudayaan, berdasarkan rumusan Koentjaraningrat (2009:165). Tradisi Tempung tawar pada masyarakat Etnis Melayu Sambas memiliki unsur bahasa, sistem pengetahuan, organisasi sosial, sistem religi, dan kesenian. Dikatakan memiliki unsur bahasa, tradisi menggunakan komunikasi bahasa lokal, Melayu Sambas dan bahasa Arab saat pembacaan doa dan pujian pada Nabi. Memiliki unsur sistem pengetahuan karena saat prosesi tidak semua orang yang terlibat paham urutan dan tata caranya. Artinya harus ada pewarisan ilmu didalamnya. Dikatakan memiliki unsur organisasi karena orang yang terlibat masing-masing memiliki peran dan tanggung jawab tersendiri. Dikatakan memiliki unsur religi karena jelas tradisi Tempung tawar diyakini sebagai sunnah nabi, dan diiringi dengan doa serta shalawat nabi. Dan terakhir memiliki unsur kesenian karena upacara inti yang diiringi shalawat nabi dipoles sedemikian rupa menjadi irama dan nada yang serasi dan diikuti tabuhan alat musik tradisional.

Kedua, perspektif etnopedagogi, berdasarkan konsep A. Chaedar Alwasilah(2009). Tradisi Tempung tawar sebagai salah satu bentuk kearifan lokal dipandang dalam perspektif etnopedagogia dapat dianggap sebagai sumber inovasi dan keterampilan yang dapat diberdayakan demi kesejahteraan masyarakat karena didalamnya terdapat etnofilosofis. Ketiga, perspektif pendidikan karakter, yakni diadaptasi berdasarkan standar Megawangi (2013: 75). Tradisi Tempung tawar melahirkan 1) nilai agama dan rasa syukur serta perjuangan melawan syaitan dapat dikontekstualisasikan menjadi karakter Cinta Allah dan kebenaran, 2) nilai kesatuan dengan alam dapat dikontekstualisasikan menjadi karakter tanggung jawab dan disiplin, dan 3) nilai sosial, cinta dan kasih sayang, serta keselamatan dan kebaikan hidup dapat dikontekstualisasikan menjadi karakter Kasih sayang, peduli dan kerja sama. 


\section{Internalisasi pendidikan karakter berbasis kearifan lokal}

Pendidikan karakter mengajarkan kebiasaan cara berpikir dan perilaku yang membantu individu untuk hidup dan bekerja bersama sebagai keluarga, masyarakat dan bernegara dan membantu mereka untuk membuat keputusan yang dapat dipertanggungjawabkan. Pendidikan karakter mencoba membantu anak untuk melaksanakan perilaku yang baik, santun dan disiplin secara terus menerus, sehingga hal-hal tersebut secara relatif menjadi mudah untuk dilakukan oleh anak serta secara relatif anak menjadi merasa tidak biasa untuk melakukan hal-hal sebaliknya.

Sementara karakter Dalam Webster's Dictionary, berarti "the aggragate features and traits thajform the apparent individual-nature of same person or thing; moral or ethical quality; qualities of honesty, courage, integrity; good reputation; an account of the cualities or peculiarities of a person or thing", Karakter merupakan totalitas dari ciri pribadi yang membentuk penampilan seseorang atau obyek tertentu. Ciri -ciri personal yang memiliki karakter terdiri dari kualitas moral dan etist, kualitas kejujuran, keberanian,. integritas, repuiasi yang baik; semua nilai tersebut di atas merupakan sebuah kualitas yang melekat pada kekhasan personal individu, Sedang menurut Ensiklopedia Indonesia, karakter memiliki arti antara lain; keseluruhan dari . perasaan dan kemauan yang tampak dari luar sebagai kebiasaan seseorang reaksi terhadap dunia luar dan impian yang diidam-idamkan (Tan Giok Lie, 2007; 37). Pengertian karakter dilihat dari sudut pendidikan, didefinisikan sebagai stuktur rohani yang eriihat dalam perbuatan, dan terbentuk oleh faktor bawaan dan pengaruh lingkungan. Karakter mengacu pada kehidupan moral dan etis seseorang untuk percaya kepada Tuhan dan sesama, yaitu kebajikan moral untuk berbuat baik.

Menurut Licona (2013:81) karakter terdiri dari nilai operatif dan nilai dalam tindakan. Kita berproses dalam karakter, sering suatu nilai menjadi suatu kebaikan, suatu disposisi batin yang dapat diandalkan untuk menanggapi situasi dengan cara menurut moral yang baik. Licona juga membagi komponen-komponen karakter kedalam tiga hal yaitu pengetahuan moral, perasaan moral dan aksi moral.

Karakter secara koheren memancar dari hasil olah pikir, olah hati, alah raga serta olah rasa dan karsa seseorang atau sekelompok orang. Karakter merupakan ciri khas seseorang atau sekelompok orang yang mengandung nilai, kemampuan, kapasitas moral dan ketegaran dalam menghadapi kesulitan dan tantangan.

Dalam hubungannya dengan pendidikan, pendidikan karakter dapat dimaknai sebagai pendidikan nilai, pendidikan budi pekerti, pendidikan moral, pendidikan watak yang bertujuan mengembangkan kemampuan siswa untuk memberikan keputusan baik-buruk, memelihara kebaikan, mewujudkan dan menebar kebaikan dalam kehidupan sehari-hari dengan sepenuh hati. 
Adapun tujuan dari pendidikan karakter yang sesungguhnya jika dihubungkan dengan falsafah Negara Republik indoensia adalah mengembangkan karakter peserta didik agar mampu mewujudkan nilai-nilai luhur pancasila.

Oleh karena itu, sosialisasi dan pendidikan masyarakat yang berkaitan dengan nilai-nilai kebajikan baik di keluarga, sekolah, maupun lingkungan yang lebih luas sangat penting dalam pembentukan karakter seseorang. Desain pendidikan karakter bergerak dari knowing menuju doing atau acting. William Kilpatrick menyebutkan salah satu penyebab ketidakmampuan seseorang berlaku baik meskipun ia telah memiliki pengetahuan tentang kebaikan itu (moral knowing) adalah karena ia tidak terlatih untuk melakukan kebaikan (moral doing). Berangkat dari pemikiran ini maka kesuksesan pendidikan karakter sangat bergantung pada ada tidaknya knowing, loving, dan doing atau acting dalam penyelenggaraan pendidikan karakter. Selanjutnya, Moral Loving atau Moral Feeling merupakan penguatan aspek emosi anak untuk menjadi manusia berkarakter. Penguatan ini berkaitan dengan bentuk-bentuk sikap yang harus dirasakan oleh anak, yaitu kesadaran akan jati diri, percaya diri (self esteem), kepekaan terhadap derita orang lain (emphaty), cinta kebenaran (loving the good), pengendalian diri (self control), kerendahan hati (humility).

Kearifan lokal merupakan produk budaya masa lalu yang patut secara terus-menerus dijadikan pegangan hidup. Meskipun bernilai lokal tetapi nilai yang terkandung di dalamnya dianggap sangat universal. Sehingga dengan mengintegrasikan kearifan lokal dalam desain pembentukan karakter anak, secara tidak langsung anak akan mendapatkan gambaran yang utuh atas identitas dirinya sebagai individu, serta identitas dirinya sebagai anggota masyarakat yang terikat dengan budaya yang ungul dan telah lama diugemi para pendahulunya.

Kearifan lokal menurut Permana (dalam Alfin 2013 hal 428) ) sebagai kebijakan setempat (local wisdom) diartikan sebagai pandangan hidup dan pengetahuan serta berbagai strategi kehidupan yang berwujud aktivitas yang dilakukan oleh masyarakat lokal dalam menjawab berbagai masalah dalam memenuhi kebutuhan mereka. Jadi kearifan lokal dapat menjadi sarana dalam melangsungkan kehidupan bahkan dapat berkembang secara berkelanjutan. Selanjutnya Anggraini dan Kusniarti (2015: 89) mendefinisikan kearifan lokal merupakan kekayaan lokal yang berisi kebijakan atau pandangan hidup. Kearifan lokal berfungsi untuk membentuk manusia menjadi lebih bijaksana dalam menjalani kehidupan mereka.

Alwasilah (2009:51) mengartikan kearifan lokal adalah koleksi fakta, konsep, kepercayaan, dan persepsi masyarakat ihwal dunia sekitar. Ini mencakup cara mengamati dan mengukur alam sekitar, menyelesaikan masalah, dan memvalidasi informasi. Singkatnya, kearifan lokal adalah proses bagaimana pengetahuan dihasilkan, disimpan, diterapkan, dikelola, dan 
diwariskan. Bahkan Alwasilah menambahkan akan ciri-ciri kearifan lokal yaitu: 1) berdasarkan pengalaman, 2) teruji setelah digunakan berabad-abad, 3) dapat diadaptasi dengan kultur kini, 4) padu dalam praktekan keseharian masyarakat dan lembaga, 5) lazim dilakukan oleh individu atau masyarakat secara keseluruhan, 6) bersifat dinamis dan terus bertambah, dan 7) sangat terkait dengan sistem kepercayaan. Dengan demikian local wisdom dapat dipahami sebagai gagasangagasan, nilai-nilai, pandangan-pandangan setempat (local) yang bersifat bijaksana, penuh kearifan, bernilai baik, yang tertanam dan diikuti oleh anggota masyarakatnya baik berupa tradisi, petuah maupun semboyan hidup. Kearifan lokal yang digali, dipoles, dikemas, dipelihara dan dilaksanakan dengan baik bisa berfungsi sebagai alternatif pedoman hidup manusia.

Pendidikan karakter berbasis kearifan lokal, pedoman nilai-nilai kearifan lokal merupakan kriteria yang menentukan kualitas tindakan anak. Sebagai sebuah kriteria yang menentukan, nilainilai kearifan lokal bisa menjadi sebuah pijakan untuk pengembangan sebuah pembelajaran yang lebih berkarakter. Kebermaknaan pembelajaran dengan lingkup kearifan lokal akan menampilkan sebuah dimensi pembelajaran yang selain memacu keilmuan seseorang, juga sekaligus bisa mendinamisasi keilmuan tersebut menjadi kontekstual dan ramah budaya daerah.

Sekaitan dengan itu Kerta Adhi (2016 :1570) menjelaskan The character of the local community with the customs and culture that have been embraced need to be considered in order to reduce poverty in the community by adopting and elaborating the values of local wisdom into a poverty alleviation strategy merujuk pada hal ini bahwa Karakter masyarakat setempat dengan adat dan budaya yang telah ada perlu diperhatikan untuk mengurangi kemiskinan yang dapat menciptakan kesejahteraan dalam masyarakat dengan mengadopsi dan mengelaborasi nilai-nilai kearifan lokal menjadi strategi pengentasan kemiskinan atau peningkatan kesejahteraan dalam hal ekonomi.

Menggali dan menanamkan kembali kearifan lokal secara inheren melalui pembelajaran, dapat dikatakan sebagai gerakan kembali pada basis nilai budaya daerahnya sendiri, sebagai bagian upaya membangun identitas bangsa dan sebagai semacam filter dalam menyeleksi pengaruh budaya "lain". Nilai-nilai kearifan lokal itu meniscayakan fungsi yang strategis bagi pembentukan karakter dan identitas bangsa. Pendidikan yang menaruh peduli terhadapnya, akan bermuara pada munculnya sikap yang mandiri, penuh inisiatif, santun dan kreatif.

Salah satu aplikasi pemanfaatan nilai-nilai kearifan lokal sebagai basis pendidikan karakter, misalnya apabila di daerah terdekat sekolah itu terdapat filosofi hidup yang merupakan landasan nilai kehidupan daerah tersebut, seperti filosofi tradisi Tempung tawaryang ada pada masyarakat melayu sambas. Maka guru dalam pembelajaran harus memulai memunculkan dan 
menginternalisasikan nilai-nilai kearifan lokal tersebut, sebagai pijakan dan spirit dalam setiap mendidik siswanya. Sehingga dari pola yang demikian, guru akan menjadi seorang fasilitator yang baik bagi internalisasi nilai-nilai kearifan lokal pada diri peserta didik yang bersinggungan langsung dalam proses pembelajaran. Nilai yang terkandung dalam bingkai kearifan lokal sebuah daerah akan menjadi senjata yang ampuh untuk membangun karakter anak bangsa, agar memiliki jiwa nasionalisme yang tinggi sekaligus mampu menjadi penjaga kelestarian kearifan lokal tersebut melalui sikap keseharian yang berkarakter kuat.

\section{SIMPULAN}

Nilai atau makna di balik tradisi Tempung tawar dalam konteks masyarakat Melayu Sambas dapat dijadikan sebagai salah satu modal dalam penguatan karakter Melayu Sambas dan jika dikontekstualisasikan ke dalamnilai-nilai kearifan lokal bisa menjadi sebuah pijakan untuk pengembangan sebuah pembelajaran yang lebih berkarakter Dengan demikian dalam konteks tulisan ini maka Tradisi Tempung tawar memiliki Nilai-Nilai Karakter yang Berbasis Kearifan Lokal Masyarakat Melayu Sambas.Tradisi Tempung tawar melahirkan 1) nilai agama, rasa syukur dapat dikontekstualisasikan menjadi karakter religius, 2) nilai kesatuan dengan alam dapat dikontekstualisasikan menjadi karakter tanggung jawab dan disiplin, dan 3) nilai sosial, cinta dan kasih sayang, serta keselamatan dan kebaikan hidup dapat dikontekstualisasikan menjadi karakter Kasih sayang, peduli dan kerja sama. Karakter yang dimunculkan tetap tidak menyimpang dari nilai-nilai religius, disamping itu juga, upaya yang berorientasi tradisi bukan berarti anti perubahan. Yang tetap bertahan adalah nilai kearifan yang terkandung di dalamnya yang harus diwariskan dari generasi ke generasi. Sementara implementasi dan aktualisasinya dalam praktik kehidupan selalu menyesuaikan dengan kondisi tuntutan zaman senantiasa berubah.

Jadi, Salah satu nilai yang dapat dijadikan sebagai pijakan pembangunan pendidikan karakter adalah memberikan pembelajaran kepada anak melalui nilai-nilai kebaikan sebuah daerah yang sudah mengakar kuat sebagai sistem budaya, yang kemudian disebut sebagai kearifan lokal. Kearifan lokal menjadi sebuah tawaran yang menarik untuk pengembangan pendidikan karakter, karena pada dasarnya pengembangan karakter harus diikuti dengan pengintegrasian jati diri kebangsaan pada diri anak, jati diri kebangsaan atau nasionalisme pasti akan berkait erat dengan jejaring kebudayaan bangsa yang menjadi basis kebudayaan nasional. 


\section{DAFTAR PUSTAKA}

Alfian, M. (2013). Potensi Kearifan Lokal dalam Pembentukan Jati Diri dan Karakter Bangsa. Prosiding The 5th International Conference on Indonesian Studies: "Ethnicity and Globalization” di Jogyakarta, Tanggal 13-14 Juli 2013.

Anggraini, P. dan Kusniati, T. 2015. The Insertion of Local Wisdom Intructional Material of Bahasa Indonesia for 10 th Grade Students in Senior High School. Journal of Education and Practice. Vol. 6, No. 33, 2015.

Alwasilah, dkk (2009). Etnopedagogi, Landasan Praktek Pendidikan dan Pendidikan Guru. Bandung: PT Kiblat Buku Utama.

Budimansyah, Dasim(2012). Perancangan Pembelajaran Berbasis Karakter. Bandung: Widya Aksara Press, 2012.

Kerta Adhi, Made (2015). The Strategy of Cultural Poverty Alleviation Based on Empowering Local Genius, International Journal of Science and Research (IJSR) ISSN (Online): 23197064, Volume 5 Issue 11, November 2016.

Koentjaraningrat (2009). Pengantar Ilmu Antropologi. Jakarta: Rineka Cipta.

Komariah, \& Satori, (2011), Metode Penelitian Kualitatif, Bandung, Alfabeta.

Lickona, Thomas (2013), Pendidikan Karakter, Panduan Lengkap Mendidik Siswa Menjadi Pintar dan Baik, Terj. Lita S,. Bandung: Nusa Media.

Maksudin (2013). Pendidikan Karakter Non-Dikotomik. Yogyakarta: Pustaka Pelajar.

Moleong, Lexy J (2007). Metodologi Penelitian Kualitatif. Bandung: PT Remaja Rosdakarya.

Mulia, Siti Musdah \& Aini, Ira D (2013). Karakter Manusia Indonesia, Butir-butir Pendidikan Karakter untuk Generasi Muda. Bandung: Nuansa Cendikia.

Muslich, Masnur (2013). Pendidikan Karakter, Menjawab Tantangan Krisis Multidimensional. Jakarta: Bumi Aksara.

Rahman, Ansar dkk., (2001) Kabupaten Sambas Sejarah Kesultanan dan Pemerintahan Daerah. Pontianak: Dinas Pariwisata Pemda Kab. Sambas

Wagiran. (2012). Pengembangan karakter berbasis kearifan local Hamemayu Hayuning Bawana, Dalam Jurnal Pendidikan Karakter. Tahun II (2), 329-339. 